\title{
Clear cell change in follicular adenoma of the thyroid. A diagnostic challenge
}

\author{
JosÉ-FeRnANDO VAL-BERNAL ${ }^{1}{ }^{1}$, MARÍA MARTINO ${ }^{2)}$ \\ 1) Pathology Unit, Department of Medical and Surgical Sciences, University of Cantabria and IDIVAL Research Institute, \\ Santander, Spain \\ ${ }^{2)}$ Service of Anatomical Pathology, Marqués de Valdecilla University Hospital and IDIVAL Research Institute, Santander, \\ Spain
}

\begin{abstract}
Clear cells in thyroid neoplasms can take two main forms: balloon-shaped and signet-ring cells. Balloon-shaped cell change in follicular adenoma is rare. A review of the literature has revealed only 20 previously published cases. We report herein a new case in the right thyroid lobe of a 45-year-old man. The clinicopathological data of the 21 cases including our paper have revealed that the ages of the patients ranged from 22-70 years, with a mean of 41.6 years. There was a clear predominance in women (M:F, 1:6). The most frequent location was in either of both lobes (81.8\%), rarely affecting the isthmus. One case was observed in an ectopic thyroid in the submandibular region. The size ranged from $0.7-5.5 \mathrm{~cm}$ (mean $2.9 \mathrm{~cm}$ ). The type of surgical intervention where this data was reported it was lobectomy for $10(55.5 \%)$ cases, thyroidectomy for six (33.3\%) cases, and simple excision for two (11.1\%) cases. In one patient, the lobectomy was accompanied by cervical lymph node dissection. No cases recurred or extended outside the thyroid. The main differential diagnoses include intrathyroidal clear cell tumor of parathyroid origin, clear cell carcinoma of follicular, oncocytic, papillary, medullary or undifferentiated (anaplastic) origin, paraganglioma, metastatic clear cell carcinoma, especially of renal origin, metastatic balloon cell melanoma, and clear large-cell lymphoma. A thyroid lesion showing clear cell change constitutes a diagnostic challenge in cytological and biopsy diagnosis. Careful observation of the routine techniques along with the aid of an adequate immunohistochemical panel is essential to reach a correct biopsy diagnosis.
\end{abstract}

Keywords: thyroid, follicular adenoma, clear cell change, balloon-cell change, signet-ring cell change, fine-needle aspiration cytology.

\section{a Introduction}

Clear cell thyroid neoplasms are very uncommon and include rare cases of follicular adenoma, oncocytic neoplasms, follicular, papillary, medullary, undifferentiated (anaplastic) carcinomas [1, 2] and certain large-cell lymphomas that may arise in the gland or affect it secondarily [3]. Other conditions with clear cell change comprise cases of ectopic parathyroid in the thyroid gland, dyshormonogenetic goiter, Hashimoto's thyroiditis, and nodular hyperplasia [4]. In addition, metastatic clear cell carcinoma principally from the kidney can manifest as a thyroid enlargement $[5,6]$.

In thyroid lesions, clear cells may represent a minor portion, a predominant component, or the exclusive element. Primary epithelial thyroid tumors in which clear cells constitute $75 \%$ or more of the tumor cells have been designed as clear cell tumors [4].

There has been some controversy regarding the potential aggressiveness of thyroid neoplasms with clear cells and whether they should be considered a specific entity. Most neoplasms with abundant clear cells have been considered in older classifications of thyroid tumors as clear cell carcinomas [1,7] or atypical adenomas [8]. Furthermore, recently some authors assert that clear cell change in thyroid neoplasia should raise the possibility of follicular carcinoma [9].

Clear cells in benign thyroid neoplasms can take two main forms namely: balloon cells [10] and signet-ring cells [11, 12]. Balloon cells are large swollen cells with clear foamy or finely granular cytoplasm. Signet-ring cells are characterized by the accumulation of intracytoplasmic materials in a large vacuole that displaces the nucleus to the periphery of the cell, causing a crescent-like appearance.

\section{Aim}

We report herein, a case of diffuse clear cell follicular adenoma of the thyroid and review the literature. The cells adopted a balloon-shaped morphology. Ballooncell change in thyroid adenoma has been reported rarely. In fact, as far as we are aware only 20 cases have been described in the literature, one in an ectopic thyroid in the submandibular region $[1,10,13-21]$.

\section{ㅁ Case presentation}

A 39-year-old man presented to the Neurology Clinic for paralysis of the left arm and half of the left face of a transient nature. A diagnostic of transient ischemic accident and antiphospholipid syndrome was established and treated with acetylsalicylic acid and folic acid. During the physical examination, a thyroid nodule was detected in the right lobe. It showed good mobility on palpation. The ultrasound (US) study revealed a single solid hypoechoic nodule with well-defined limits and peripheral vascularization, in the lower pole of the right lobe, the major axis of which was $1 \mathrm{~cm}$. This nodule was classified as Thyroid Imaging Reporting and Data System (TI-RADS)

This is an open-access article distributed under the terms of a Creative Commons Attribution-NonCommercial-ShareAlike 4.0 International Public License, which permits unrestricted use, adaptation, distribution and reproduction in any medium, non-commercially, provided the new creations are licensed under identical terms as the original work and the original work is properly cited. 
4a. In addition, a slightly hypoechogenic polylobed lesion with no well-defined limits was detected in the middle third of the left lobe, $1.15 \mathrm{~cm}$ in maximum diameter. The lesion was also classified as TI-RADS 4a. No cervical enlarged lymph nodes were observed. Fine-needle aspiration cytology (FNAC) diagnoses were follicular neoplasia in the right lobe and follicular lesion of undetermined significance in the left lobe. The analytical study showed that the lesions in both lobes were non-functional.

After two years, the neurological symptoms had not recurred and antiphospholipid antibodies had normalized. Three years later, he presented with a sleep disorder that was classified as moderate supine apnea-hypopnea syndrome treated with automatic positive pressure in the airway. A year later, he consulted for a Bennett fracture of the left hand without displacement that was treated with immobilization. A new US study of the thyroid revealed that the lesions had slightly increased in size. The nodule of the right lobe measured $1.5 \mathrm{~cm}$ of maximum axis and that of the left lobe $2 \mathrm{~cm}$. The TI-RADS rating scale remained the same for both lobe lesions. The new cytological diagnoses were similar to the previous ones. An otorhinolaryngological study showed no abnormalities. The patient underwent total thyroidectomy six years after the first consultation. Postoperatively, there were no complications. Blood calcium and parathyroid hormone (PTH) levels were normal. Both thoracoabdominal and abdominopelvic computed tomography scans with contrast showed no significant changes. The patient was doing well three months after the intervention.

\section{Cytopathological findings}

FNACs were performed on the patient with US control. The cytological smears were fixed in an ethanol solution or air dried and stained with the Papanicolaou (Pap) and Diff-Quik methods. FNAC of the right lower lobe revealed moderate cellularity. There were groups of clear cells or microfollicular structures with a diffusely vacuolated cytoplasm (Figure 1A). The cell borders were moderately defined. The nuclei were round, hyperchromatic, with homogenous chromatin, and visible single nucleoli. Modest nuclear anisokaryosis was identified. Nuclear pseudoinclusions or grooves were no present. Colloid was very scant. Based on these findings the successive diagnoses in two samples were follicular neoplasia (Figure 1, B and C). FNAC of the left lobe showed moderate cellularity with follicular cells in plates and little colloid. Some cells showed irregular nuclei with grooves. Lymphocytes were seen in the background of the smears. The cytological diagnoses in two samples were follicular lesion of undetermined significance.

\section{Histopathological findings}

The thyroid weighed $20 \mathrm{~g}$ and measured $7 \times 5 \times 3 \mathrm{~cm}$. The right lower lobe contained a $2 \mathrm{~cm}$ diameter encapsulated, solid, pale tan, fleshy, nodular lesion (Figure 2). The left lobe showed two brown, non-encapsulated, poorly circumscribed nodules measuring $2 \mathrm{~cm}$ and $0.3 \mathrm{~cm}$ located in the middle zone.

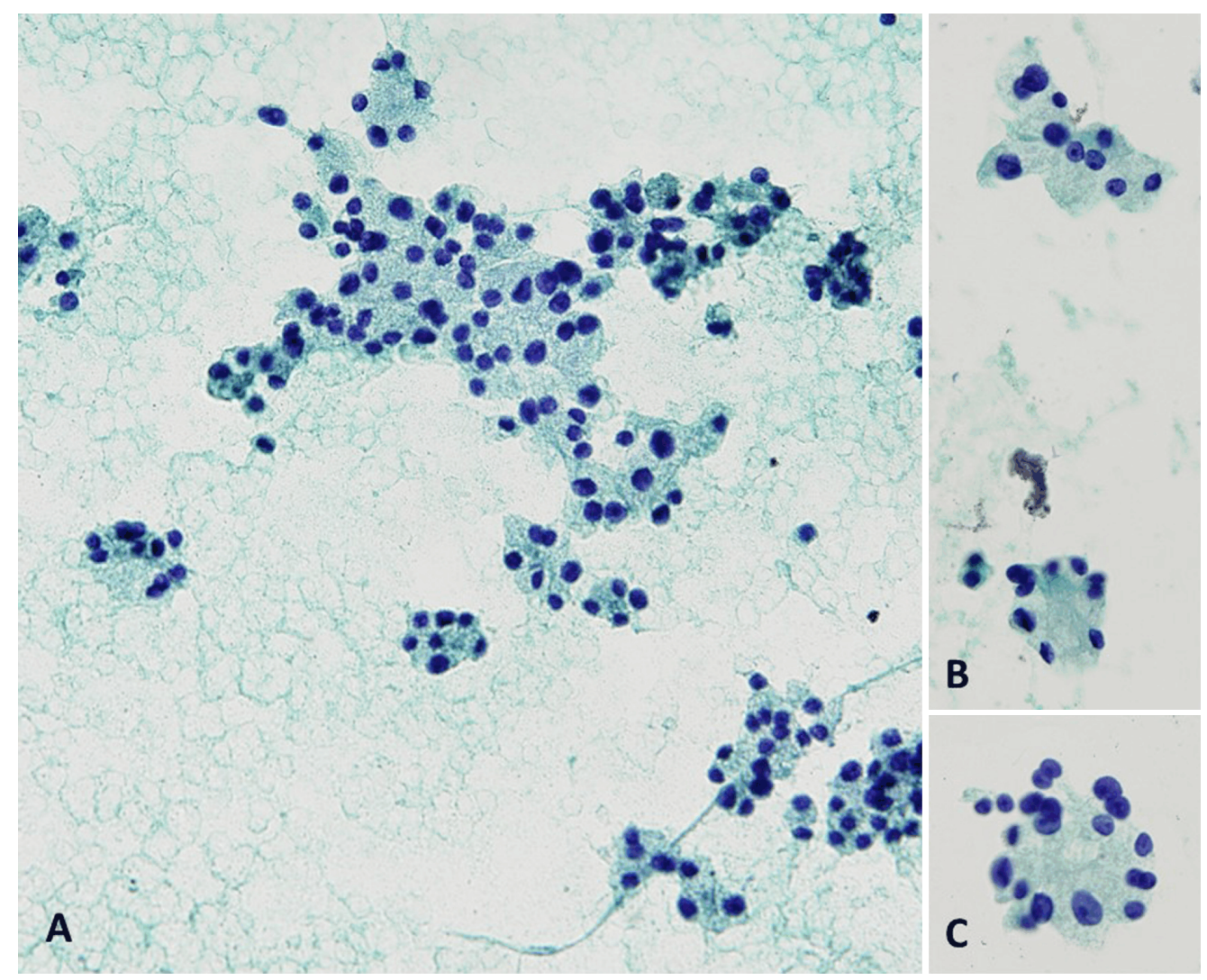

Figure 1 - Fine-needle aspiration cytology. First study: (A) Groups and microfollicles of clear balloon-shaped cells showing abundant fine vesicles in their cytoplasm. Second study: (B) A cluster and a microfollicle of clear balloonshaped cells can be seen - nuclei are round with a visible nucleolus; (C) A microfollicle is displaying a central lumen - there is slight anisokaryosis. Papanicolaou (Pap) staining: $(A-C) \times 400$. 


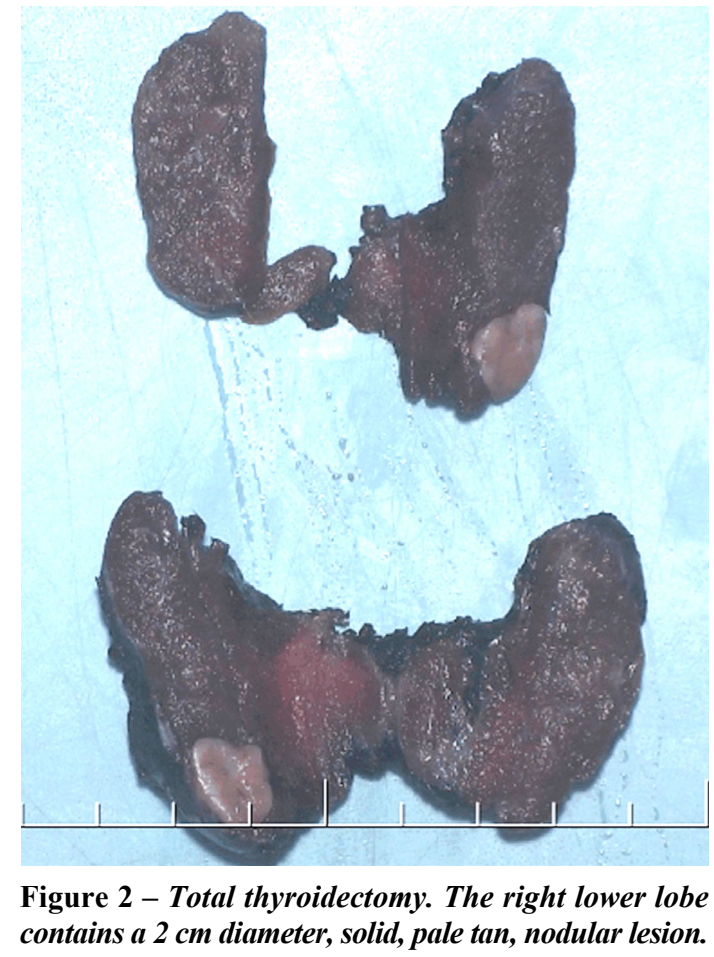

The entire surgical specimen was fixed in $10 \%$ neutral buffered formalin. Representative tissue samples were embedded in paraffin. For routine microscopy, 4- $\mu \mathrm{m}$ thick sections were stained with Hematoxylin and Eosin (HE), Alcian Blue (pH 2.5), Periodic Acid-Schiff (PAS), PAS-Diastase digestion method, and Mayer's Mucicarmine method. Immunohistochemical (IHC) staining was performed using the EnVision FLEX+ Visualization System (Dako, Agilent Technologies, SL, Las Rozas, Madrid, Spain). The IHC reaction was performed using appropriate tissue controls for the antibodies utilized. Automatic staining was accomplished on a Dako Omnis stainer (Agilent Technologies, SL). Antibodies used are detailed in Table 1.

The nodular lesion of the right lobe was well circumscribed, with a thin smooth capsule of fibrous connective tissue (Figure 3A). The cells were grouped in solid areas showing a diffuse, trabecular, or nesting pattern of growth (Figure 3B) with occasional formation of microfollicular structures with central lumen surrounded by clear cells (Figure 4A). The lumens contained PAS-positive colloid (Figure 4B). These cells were large, round to polyhedral, with an abundant clear cytoplasm showing an extremely fine granularity due to fine vesicles. Negative Alcian Blue and Mucicarmine stainings in these cells excluded the presence of mucin. The PAS staining accentuated the cytoplasmic granularity (Figure 4B) and this reaction was diastase resistant indicating the absence of glycogen. The nuclei were central, regular, often with visible nucleoli. The vascularity within the lesion was not prominent. After multiple sections, there was no evidence of multinucleated giant balloon cells, spindle cell component, necrosis, mitoses, and extracapsular growth or vascular invasion.

The IHC panel revealed the tumor cells positive for pan-cytokeratin (CK) AE1/AE3 (Figure 5A), thyroglobulin
(TGB) (Figure 5B), paired box gene 8 protein (PAX8) (Figure 5C), and thyroid transcription factor-1 (TTF-1) (Figure 5D), whereas no immunoreactivity was seen for renal cell carcinoma marker (RCCM), cluster of differentiation 10 (CD10), carbonic anhydrase IX (CAIX), anti-mitochondrial antibody (AMA), PTH, p53 protein, anti-human melanosome [human melanoma black 45 (HMB45)], S100 protein, and smooth muscle actin (SMA). The Ki67 index was around 1\%. A diagnosis of complete clear cell change in follicular adenoma of the thyroid was made. Besides, intrathyroidal ectopic parathyroid without histological abnormalities was also found in the right lower lobe. The nodules of the left lobe corresponded to conventional hyperplasic nodules.

Table 1 - IHC antibodies used in this study

\begin{tabular}{|c|c|c|c|c|}
\hline Antibody & Source & Clone & Dilution & $\begin{array}{l}\text { Retrieval } \\
\text { solution } \\
\text { pH (Dako) }\end{array}$ \\
\hline AMA & BioGenex & $113-1$ & $1: 400$ & High \\
\hline Pan-CK & Dako & AE1/AE3 & $\begin{array}{c}\text { FLEX } \\
\text { RTU }\end{array}$ & High \\
\hline CD10 & Dako & $56 \mathrm{C} 6$ & $\begin{array}{c}\text { FLEX } \\
\text { RTU }\end{array}$ & High \\
\hline CAIX & Abcam & Polyclonal & $1: 1000$ & Low \\
\hline $\begin{array}{l}\text { Anti-human } \\
\text { melanosome }\end{array}$ & Dako & HMB45 & $\begin{array}{c}\text { FLEX } \\
\text { RTU }\end{array}$ & High \\
\hline Ki-67 & Dako & MIB-1 & $\begin{array}{c}\text { FLEX } \\
\text { RTU }\end{array}$ & Low \\
\hline PAX8 & ProteinTech & Polyclonal & $1: 400$ & Low \\
\hline p53 protein & Dako & DO-7 & $\begin{array}{c}\text { FLEX } \\
\text { RTU }\end{array}$ & High \\
\hline PTH & Nordic BioSite & Polyclonal & $1: 200$ & High \\
\hline $\mathrm{RCCM}$ & Dako & SPM314 & $\begin{array}{l}\text { FLEX } \\
\text { RTU }\end{array}$ & Low \\
\hline SMA & Dako & $1 \mathrm{~A} 4$ & $\begin{array}{c}\text { FLEX } \\
\text { RTU }\end{array}$ & High \\
\hline S100 protein & Abcam & Ab55787 & $1: 100$ & High \\
\hline TGB & Dako & Polyclonal & $\begin{array}{c}\text { FLEX } \\
\text { RTU }\end{array}$ & High \\
\hline TTF-1 & Dako & $8 \mathrm{G} 7 \mathrm{G} 3 / 1$ & $\begin{array}{c}\text { FLEX } \\
\text { RTU }\end{array}$ & High \\
\hline
\end{tabular}

IHC: Immunohistochemical; AMA: Anti-mitochondrial antibody; Pan-CK: Pan-cytokeratin; CD10: Cluster of differentiation 10; CAIX: Carbonic anhydrase IX; HMB45: Human melanoma black 45; PAX8: Paired box gene 8 protein; PTH: Parathyroid hormone; RCCM: Renal cell carcinoma marker; SMA: Smooth muscle actin; TGB: Thyroglobulin; TTF-1: Thyroid transcription factor-1; Abcam, Cambridge, UK; BioGenex (Izasa, SA, Barcelona, Spain); Dako (Agilent Technologies, SL, Las Rozas, Madrid, Spain); Nordic BioSite, Täby, Sweden; ProteinTech, Barcelona, Spain; RTU: Ready-to-use.

\section{Discussions}

Thyroid cell lesions composed predominantly (75$100 \%$ ) of clear cells are uncommon and constitute a heterogeneous group of processes. They can include nonneoplastic lesions, benign tumors, malignant primitive tumors, and metastatic tumors. Clear cell change in adenoma can occur in two ways namely signet-ring cell and balloon-shaped cell. Signet-ring cells show a large, discrete cytoplasmic vacuole containing TGB, mucosubstances [11, 12, 22], or lipid. In the case of lipid-rich adenoma, the cells besides a signet ring appearance show a lipoblast-like feature with multiple vacuoles that indent the nucleus [23, 24]. 


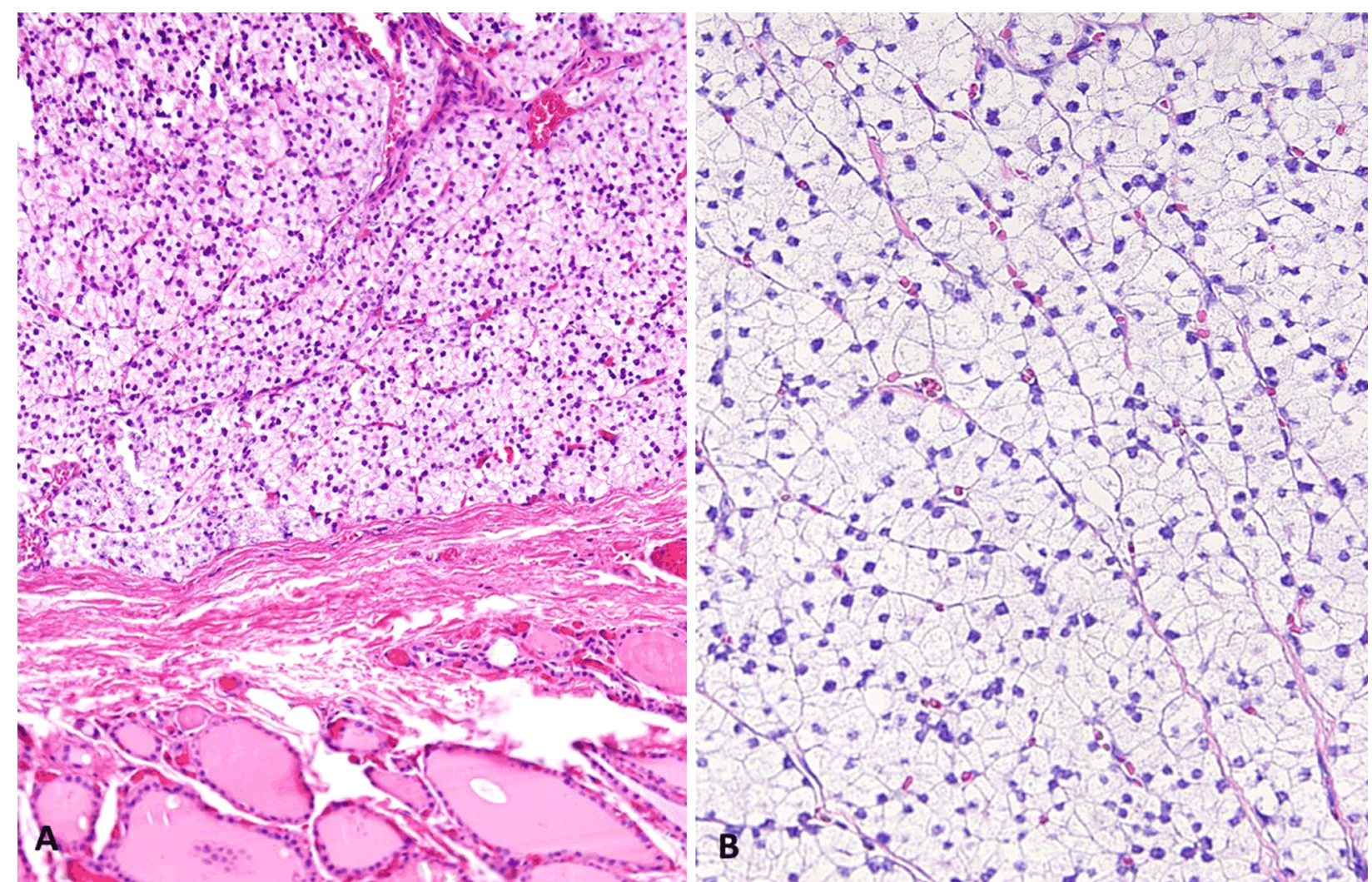

Figure 3 - Histopathology of the follicular adenoma with clear cell change: (A) Well-circumscribed lesion with a thin smooth capsule of fibrous connective tissue; (B) Trabeculae and solid nests of clear balloon-shaped cells containing fine vesicles - many nuclei are central, hyperchromatic and show a single nucleolus. Hematoxylin-Eosin (HE) staining: $(A$ and $B) \times 400$.

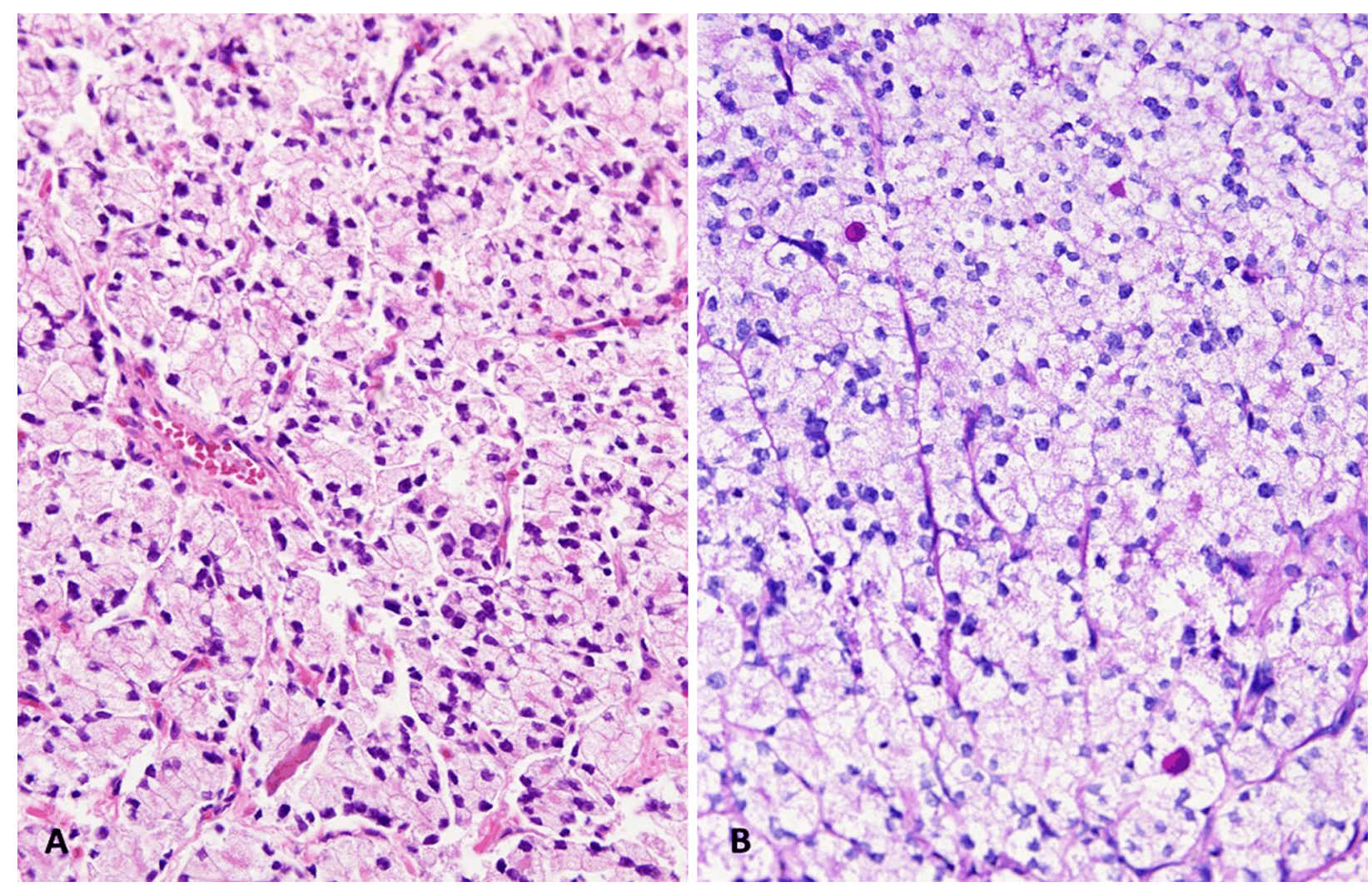

Figure 4 - Architecture of the follicular adenoma with clear cell-change: (A) Microfollicular architecture, structures with a central lumen are surrounded by clear cells - scant amount of colloid shows pale eosinophilic staining; (B) Central lumina are occupied by PAS-positive colloid - the PAS staining accentuates the cytoplasmic granularity produced by the confluence of fine cytoplasmic vesicles. Hematoxylin-Eosin $(H E)$ staining: $(A) \times 400$. Periodic Acid-Schiff $(P A S)$ staining: $(B) \times 400$. 


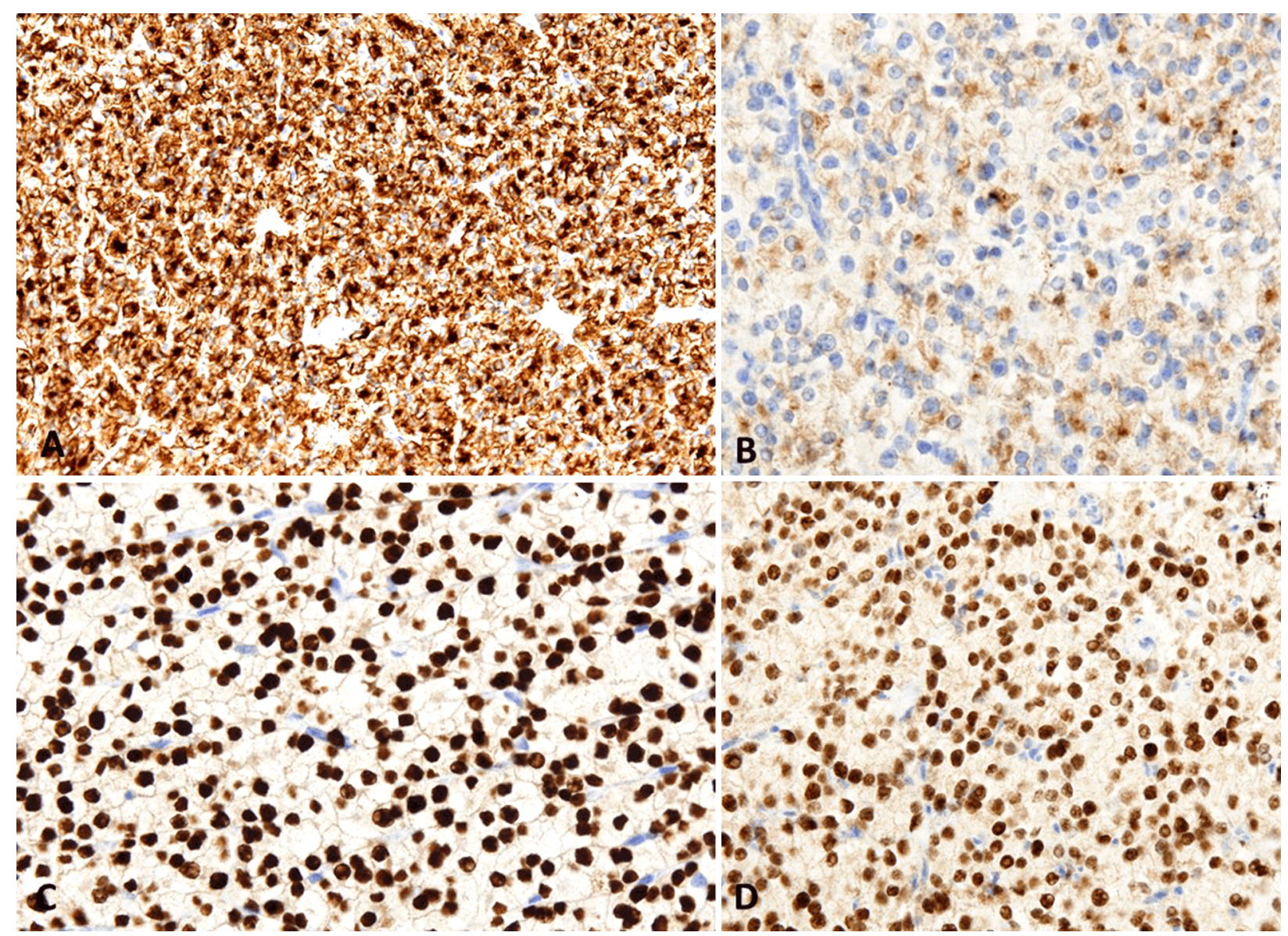

Figure 5 - IHC reactivity of the follicular adenoma with clear cell change. The clear balloon-shaped cells show positivity for pan-CK AE1/AE3 (A, ×200), TGB (B, ×400), PAX8 (C, ×400), and TTF-1 (D, ×400). IHC: Immunohistochemical; Pan-CK: Pan-cytokeratin; TGB: Thyroglobulin; PAX8: Paired box gene 8 protein; TTF-1: Thyroid transcription factor-1.

Clear cells in the cytological smears as seen in our case have uncommonly been reported in FNAC [10, 25-27]. The presence of these cells creates a complex differential diagnosis that includes benign or malignant primary thyroid tumors and metastatic neoplasms. Malignant follicular carcinomas with clear cells are characterized by very cellular smears. Tumor cells are usually monomorphic, and they are arranged in clusters or acinar structures [26]. However, some authors informed about the difficulty of the cytological staining for TGB [25].

Diagnostic histopathological criteria for clear, balloonshaped cell follicular adenoma include: $(i)$ encapsulated tumor, (ii) with evidence of follicular cell differentiation, (iii) with presence of abundant clear balloon-shaped cells $(\geq 75 \%$ ), and (iv) not invading through the capsule and/or growing into the blood vessels. Minute follicles with a dot-like intraluminal PAS-positive colloid surrounded by a ring of balloon cells can be helpful. Confirming the results of other authors, we did not find mucin, lipid, or significant glycogen in the tumor cells. The neoplasm characteristically shows positivity for pan-CK AE1/AE3, TGB, PAX8, and TTF-1. The cytoplasmic empty vesicles are membrane-bound and represent a degenerative phenomenon. They are believed to derive from the Golgi apparatus [14], endoplasmic reticulum [10] or both [19].

Balloon-cell change in follicular adenoma is rare. A review of the literature has revealed only 20 published cases [1, 10, 13-21]. In this review, we have not included cases diagnosed with uncertain [28] or undetermined malignant potential [1] and those in which the clear cell change presumably affected less than $75 \%$ of the lesion [27]. The clinicopathological data of the previously reported 20 cases of follicular adenoma with balloon-cell change, as well as our case are summarized in Table 2.

The study of these 21 cases has revealed that the ages of the patients ranged from 22 years to 70 years, with a mean and median of 41.6 [standard deviation (SD) 12.8] years and 41 years, respectively. There was a clear predominance in women (M:F, 1:6). The most frequent location was in either of both lobes $(81.8 \%)$ rarely affecting the isthmus $[13,15]$. One case was observed in an ectopic thyroid in the right angle of the jaw [18]. The size ranged from $0.7 \mathrm{~cm}$ to $5.5 \mathrm{~cm}$ (mean $2.9, \mathrm{SD} 1.4 \mathrm{~cm}$, median $2.5 \mathrm{~cm}$ ). The type of surgical intervention was lobectomy for $10(55.5 \%)$ cases, thyroidectomy for six (33.3\%) cases, and excision for two (11.1\%) cases. In one case, the lobectomy was accompanied by lymph node dissection [19]. No cases recurred or extended outside the thyroid.

The main differential diagnoses include intrathyroidal clear cell tumor of parathyroid origin, clear cell carcinoma of follicular, oncocytic, papillary, medullary or undiffer- 
entiated (anaplastic) origin, paraganglioma, metastatic clear cell carcinoma, especially of renal origin, metastatic balloon-cell melanoma, and clear large-cell lymphoma. Intrathyroidal parathyroid may be affected by water-clear cell hyperplasia and water-clear adenoma [29, 30].

Table 2 - Published cases of clear cell thyroid adenomas with balloon-shaped morphology

\begin{tabular}{|c|c|c|c|c|c|}
\hline $\begin{array}{l}\text { Case No./ } \\
\text { [Reference] }\end{array}$ & $\begin{array}{c}\text { Age } \\
\text { [years]/ } \\
\text { Gender }\end{array}$ & Location & $\begin{array}{l}\text { Size } \\
{[\mathrm{cm}]}\end{array}$ & $\begin{array}{c}\text { Percentage } \\
\text { of clear } \\
\text { cells }\end{array}$ & $\begin{array}{c}\text { Operation/ } \\
\text { outcome, } \\
\text { follow-up } \\
\text { [years] }\end{array}$ \\
\hline $1 /[13]$ & $38 / F$ & Isthmus & NA & Pred & $\begin{array}{c}\text { Thy/ } \\
\text { A\&W, } 9\end{array}$ \\
\hline $2 /[13]$ & $46 / F$ & $\begin{array}{l}\text { Left } \\
\text { lobe }\end{array}$ & 5.5 & Pred & $\begin{array}{c}\text { Lob/ } \\
\text { A\&W, } 0.5\end{array}$ \\
\hline $3[14]$ & $61 / F$ & $\begin{array}{l}\text { Left } \\
\text { lobe }\end{array}$ & NA & 100 & $\begin{array}{c}\text { Lob/ } \\
\text { A\&W, } 0.5\end{array}$ \\
\hline $4[14]$ & $41 / F$ & NA & 4 & 100 & $\begin{array}{c}\mathrm{NA} / \\
\mathrm{A} \& \mathrm{~W}, 2\end{array}$ \\
\hline $5 /[1]$ & $33 / F$ & NA & NA & 100 & Lob/NA \\
\hline 6/[1] & $39 / F$ & NA & NA & 100 & $\begin{array}{c}\text { Lob/ } \\
\text { A\&W, } 10\end{array}$ \\
\hline $7 /[1]$ & $48 / \mathrm{M}$ & NA & NA & 100 & $\begin{array}{c}\text { Thy/ } \\
\text { A\&W, } 1\end{array}$ \\
\hline 8/[1] & $22 / F$ & NA & NA & 100 & $\begin{array}{c}\text { Lob/ } \\
\text { A\&W, } 4\end{array}$ \\
\hline $9 /[1]$ & $70 / F$ & NA & NA & 100 & $\begin{array}{c}\text { Thy/ } \\
\text { A\&W, } 3\end{array}$ \\
\hline 10/[1] & $52 / F$ & NA & NA & 80 & Lob/NA \\
\hline $11 /[1]$ & $50 / F$ & NA & NA & 80 & $\begin{array}{c}\text { Lob/ } \\
\text { A\&W, } 1\end{array}$ \\
\hline $12 /[15]$ & $27 / F$ & $\begin{array}{c}\text { Right } \\
\text { lobe and } \\
\text { isthmus }\end{array}$ & 2.5 & 100 & $\begin{array}{c}\text { Excision/ } \\
\text { A\&W, } 2\end{array}$ \\
\hline $13 /[10]$ & $37 / F$ & $\begin{array}{l}\text { Right } \\
\text { lobe }\end{array}$ & 4.2 & 100 & Thy/NA \\
\hline $14 /[16]$ & $44 / F$ & NA & NA & NA & $\begin{array}{c}\mathrm{NA} / \\
\mathrm{A} \& \mathrm{~W}, \mathrm{NA}\end{array}$ \\
\hline $15 /[16]$ & $26 / F$ & NA & NA & NA & NA/NA \\
\hline 16/[17] & $47 / F$ & $\begin{array}{c}\text { Right } \\
\text { lobe }\end{array}$ & 2.2 & 100 & Thy/NA \\
\hline 17/[18] & $29 / F$ & $\begin{array}{c}\text { Ectopic, } \\
\text { right } \\
\text { angle of } \\
\text { the jaw }\end{array}$ & 2 & 100 & $\begin{array}{c}\text { Excision/ } \\
\text { NA }\end{array}$ \\
\hline 18/[19] & $29 / F$ & $\begin{array}{l}\text { Left } \\
\text { lobe }\end{array}$ & 0.7 & 100 & $\begin{array}{l}\text { Lob and } \\
\text { lymph } \\
\text { node } \\
\text { dissection/ } \\
\text { NA }\end{array}$ \\
\hline 19/[20] & $61 / M$ & $\begin{array}{l}\text { Right } \\
\text { lobe }\end{array}$ & 2.6 & 100 & Lob/NA \\
\hline $20 /[21]$ & $28 / F$ & $\begin{array}{l}\text { Left } \\
\text { lobe }\end{array}$ & 3 & 100 & Lob/NA \\
\hline $\begin{array}{l}21 / \text { Our } \\
\text { report }\end{array}$ & $45 / M$ & $\begin{array}{l}\text { Right } \\
\text { lobe }\end{array}$ & 2 & 100 & $\begin{array}{c}\text { Thy/ } \\
\text { A\&W, } 0.2\end{array}$ \\
\hline
\end{tabular}

F: Female; M: Male; NA: Not ascertained; Pred: Predominant; Thy: Thyroidectomy; A\&W: Alive and well; Lob: Lobectomy.

Clinical suspicion can be low due to normal serum calcium levels in some cases. Besides, these parathyroid lesions may show follicular formation, papillary fragments, and colloid [29, 30]. Furthermore, renal cell carcinoma antigen has been reported positive in parathyroid adenomas $[29,30]$. However, cells are positive for PTH IHC staining and negative for TGB. The criteria for malignancy for a clear follicular tumor include capsular or blood vessel invasion $[1,4]$. Clear cell oncocytic tumors are characterized by vesicular swelling of mitochondria. This change can be detected with anti-mitochondrial antibody or ultrastructural study. The diagnosis of malignancy is obvious when the tumor invades the capsule or blood vessels. Clear cell change is more common in the follicular variant of papillary carcinoma than in the conventional type [4]. The optically clear nuclei, pseudoinclusions, and nuclear grooves are diagnostic features. Medullary carcinoma rarely is made up of clear cells [2]. The tumor can show some degree of follicle formation. Deposits of amyloid substance in the stroma are observed in up to $90 \%$ of cases. Immunohistochemically, tumor cells are reactive for calcitonin and neuroendocrine markers, such as chromogranin $\mathrm{A}(\mathrm{CgA})$ and synaptophysin (Syn) and unreactive for TGB. Ultrastructurally, the tumor contains densecore secretory granules [4]. Clear cell undifferentiated (anaplastic carcinoma) of thyroid origin [31-33] can be difficult to distinguish from metastatic renal carcinoma. Mitoses may be numerous [31] and tumor cell cannibalism occasional [33]. Tumor necrosis foci, hemorrhage [31, 32], and numerous lymphocytes and plasma cells can be present in the stroma [31, 33]. IHC methods detected in two cases the presence of intracytoplasmic TGB [32]. Lowmolecular-weight keratin [34] and PAX8 are considered useful markers for this neoplasm $[35,36]$. The ultrastructural study can show cells containing tonofilament bundles and keratohyalin granules suggestive of squamous differentiation [31, 33]. Paragangliomas can show clear cells. Neoplastic cells are arranged in nests with a characteristic "zellballen" pattern. Tumors present positivity for CgA, Syn, neuron-specific enolase (NSE), and tyrosine hydroxylase in chief tumor cells, and S100 protein and glial fibrillary acidic protein (GFAP) in sustentacular cells [37]. CKs 7, 8, and 19 are negative. Clear cell renal cell carcinoma (CCRCC) may present as a thyroid nodule, while the primary renal tumor is silent $[5,6]$. Distinguishing this tumor from clear cell thyroid adenoma by routine staining is difficult. Metastatic CCRCC usually lacks complete encapsulation and shows prominent vascularization in the stroma. The cells show diastasesensitive PAS-positive material and are Oil Red O reactive. An IHC panel highly sensitive for this tumor includes TTF-1, TGB, CAIX [38], CD10, and RCCM. Metastatic balloon cell melanoma stains positive for $\mathrm{S} 100$ protein, HMB45, Melan-A, natural killer 1/complement component 3 (NK1/C3) (anti-CD63 antibody) [39-41], and SRY-box transcription factor 10 (SOX10) [42]. Clear large-cell lymphoma may simulate an epithelial tumor but displays a distinctive IHC lymphoma panel including positivity for leukocyte common antigen (CD45) [43, 44] and negativity for pan-CK.

\section{ㅁ Conclusions}

When the pathologist faces a tumor with clear balloonshaped cells in cytology or biopsy, the diagnostic spectrum is broad. The problem can be solved with a careful routine assessment including HE and PAS stainings and the use of an adequate IHC panel. TGB immunostaining is a specific marker for thyroid follicular cells and allows separating tumors of non-thyroid origin. The criteria for 
malignancy are the same as for conventional follicular tumors: invasion through the capsule and/or intravascular growth. It should be noted that the cytological IHC study may be compromised due to methodological difficulties.

\section{Conflict of interests}

The authors declare that they have no conflict of interests.

\section{Compliance with ethical standards}

No Ethics Committee approval is required in our institution for a case report involving a single patient.

\section{Consent}

Written informed consent was obtained from the patient for publication of this case report and all accompanying images.

\section{Funding}

This study was not funded externally.

\section{References}

[1] Carcangiu ML, Sibley RK, Rosai J. Clear cell change in primary thyroid tumors. A study of 38 cases. Am J Surg Pathol, 1985 9(10):705-722. https://doi.org/10.1097/00000478-19851000 0-00002 PMID: 4061729

[2] Landon G, Ordóñez NG. Clear cell variant of medullary carcinoma of the thyroid. Hum Pathol, 1985, 16(8):844-847. https://doi.org/10.1016/s0046-8177(85)80257-4 PMID: 4018781

[3] Wick MR, Ritter JH, Humphrey PA, Nappi O. Clear cell neoplasms of the endocrine system and thymus. Semin Diagn Pathol, 1997, 14(3):183-202. PMID: 9279975

[4] Rosai J, DeLellis RA, Carcangiu ML, Frable WJ, Tallini G. Tumors of the thyroid and parathyroid glands. Atlas of Tumor Pathology, Series 4, Fascicle 21, US Armed Forces Institute of Pathology (AFIP), American Registry of Pathology, Silver Spring, Maryland, 2014, 221-239.

[5] Heffess CS, Wenig BM, Thompson LD. Metastatic renal cell carcinoma to the thyroid gland: a clinicopathologic study of 36 cases. Cancer, 2002, 95(9):1869-1878. https://doi.org/ 10.1002/cncr.10901 PMID: 12404280

[6] Kaliszewski K, Szkudlarek D, Kasperczak M, Nowak Ł. Clear cell renal carcinoma metastasis mimicking primary thyroid tumor. Pol Arch Intern Med, 2019, 129(3):211-214. https:// doi.org/10.20452/pamw.4425 PMID: 30688287

[7] Meissner WA, Warren S. Tumors of the thyroid glands. Atlas of Tumor Pathology, Series 2, Fascicle 4, US Armed Forces Institute of Pathology (AFIP), Washington, DC, 1969, 93-94.

[8] Hazard JB, Kenyon R. Atypical adenoma of the thyroid. Arch Pathol, 1954, 58(6):554-563. PMID: 13217570

[9] Cipriani NA, Agarwal S, Dias-Santagata D, Faquin WC Sadow PM. Clear cell change in thyroid carcinoma: a clinicopathologic and molecular study with identification of variable genetic anomalies. Thyroid, 2017, 27(6):819-824. https://doi. org/10.1089/thy.2016.0631 PMID: 28293986

[10] Sobel HJ, Lamovec J, Us-Krasovec M, Zitnik V. Benign clear cell thyroid tumor with "balloon cell" change: evidence suggesting its pathogenesis. Ultrastruct Pathol, 1993, 17(3-4): 469-475. https://doi.org/10.3109/01913129309027792 PMID: 8266606

[11] Farhat NA, Onenerk AM, Krane JF, Dias-Santagata D, Sadow PM, Faquin WC. Primary benign and malignant thyroid neoplasms with signet ring cells: cytologic, histologic, and molecular features. Am J Clin Pathol, 2017, 148(3):251-258. https://doi.org/10.1093/ajcp/aqx074 PMID: 28821194

[12] Yalta T, Elagoz S, Uyar M, Topuz O, Ozer H, Tuncer E. Signet ring cell adenoma of the thyroid: a very rare entity. Med Princ Pract, 2010, 19(1):76-78. https://doi.org/10.1159/ 000252840 PMID: 19996625

[13] Chesky VE, Hellwig CA, Barbosa E. Clear cell tumors of the thyroid. Surgery, 1957, 42(2):282-289. PMID: 13455347

[14] Stoll W, Lietz H. Zur kenntnis und Problematik des hellzelligen Adenomes in der Schilddrüse [Clear-cell adenoma of the thyroid gland]. Virchows Arch A Pathol Anat, 1973, 361(2): 163-173. https://doi.org/10.1007/BF00557845 PMID: 4203386
[15] Chen KT. Clear cell follicular adenoma of the thyroid. J Surg Oncol, 1987, 34(3):170-171. https://doi.org/10.1002/jso.293 0340307 PMID: 3821125

[16] Shimizu K, Nagahama M, Kitamura Y, Chin K, Kitagawa W, Shibuya T, Mimura T, Ozaki O, Sugino K, Ito K, Tanaka S. Clinicopathological study of clear-cell tumors of the thyroid: an evaluation of 22 cases. Surg Today, 1995, 25(12):10151022. https://doi.org/10.1007/BF00311685 PMID: 8645933

[17] Sauer T, Olsholt R. Clear cell follicular adenoma of the thyroid: a case report. Diagn Cytopathol, 1996, 15(2):124-126. https:// doi.org/10.1002/(SICI)1097-0339(199608)15:2<124::AID-DC 8>3.0.CO;2-I PMID: 8872434

[18] Giri D, Gultekin SH, Ward RF, Hurley JR, Hoda SA. Clearcell follicular adenoma of ectopic thyroid in the submandibular region. Endocr Pathol, 1998, 9(4):347-351. https://doi.org/10. 1007/BF02739695

[19] Nishimura R, Noguchi M, Tsujimoto M, Noro H, Kido T, Nakahara M, Nakao K. Thyroid clear cell adenoma with marked dilatation of membranous structures: electron-microscopic study. Ultrastruct Pathol, 2001, 25(5):361-366. https://doi.org/ 10.1080/019131201317101234 PMID: 11758717

[20] Westhoff CC, Hoffmann S, Barth PJ. Clear cell follicular adenoma of the thyroid - a challenge in intra-operative diagnostics. Exp Clin Endocrinol Diabetes, 2010, 118(1):1921. https://doi.org/10.1055/s-0028-1102945 PMID: 19235130

[21] Gupta P, Gupta P, Lal N, Srivastava AN. Follicular adenoma thyroid with clear cell changes - a rare case report. Int J Adv Res, 2016, 4(6):1136-1140. https://doi.org/10.21474/IJAR01/ 699

[22] Rigaud C, Peltier F, Bogomoletz WV. Mucin producing microfollicular adenoma of the thyroid. J Clin Pathol, 1985, 38(3): 277-280. https://doi.org/10.1136/jcp.38.3.277 PMID: 3973051 PMCID: PMC499124

[23] Ranaldi R, Goteri G, Bearzi I. Lipid-rich adenoma of the thyroid. Pathol Res Pract, 1993, 189(9):1101-1106; discussion 11061107. https://doi.org/10.1016/S0344-0338(11)80693-X PMID: 8302729

[24] Chetty R. Thyroid follicular adenoma composed of lipid-rich cells. Endocr Pathol, 2011, 22(1):31-34. https://doi.org/10. 1007/s12022-010-9143-6 PMID: 21165779

[25] Ropp BG, Solomides C, Palazzo J, Bibbo M. Follicular carcinoma of the thyroid with extensive clear-cell differentiation: a potential diagnostic pitfall. Diagn Cytopathol, 2000, 23(3): 222-223. https://doi.org/10.1002/1097-0339(200009)23:3<222:: aid-dc19>3.0.co;2-8 PMID: 10945916

[26] Jayaram G. Cytology of clear cell carcinoma of the thyroid. Acta Cytol, 1989, 33(1):135-136. PMID: 2916360

[27] Orlando CA, Salman K, Miller JL, Naryshkin S. Clear-cell change in follicular adenoma mimicking Hürthle-cell tumor on thyroid aspiration biopsy cytology. Diagn Cytopathol, 1991, 7(3):273-276. https://doi.org/10.1002/dc.2840070312 PMID: 1879263

[28] Juhlin CC, Bränström R, Shabo I, Höög A. Clear cell variant of a follicular thyroid tumor with uncertain malignant potential: a case report. Int J Surg Pathol, 2019, 27(3):290-293. https:// doi.org/10.1177/1066896918809490 PMID: 30370813

[29] Papanicolau-Sengos A, Brumund K, Lin G, Hasteh F. Cytologic findings of a clear cell parathyroid lesion. Diagn Cytopathol, 2013, 41(8):725-728. https://doi.org/10.1002/dc. 22806 PMID: 22144114

[30] Pirela D, Treitl D, El Hussein S, Poppiti R, Mesko T, Manzano A Intrathyroidal clear cell tumor of parathyroid origin with review of literature. Case Rep Pathol, 2016, 2016:7169564. https:// doi.org/10.1155/2016/7169564 PMID: 28003924 PMCID: PMC5149621

[31] Wassef M, Monteil JP, Bourgeon F, Le Charpentier Y. Carcinome indifférencié à cellules claires de la thyroïde. Intérêt diagnostique de l'étude ultrastructurale [Undifferentiated clear cell thyroid carcinoma. Diagnostic interest of ultrastructural study]. Ann Pathol, 1981, 1(1):95-98. PMID: 7195726

[32] Péter I, Besznyák I, Szántó J, Füzy M, Bodó M, Sugár J. Clear cell thyroid cancer - undifferentiated type - an immunohistochemical and electron microscopical study. Arch Geschwulstforsch, 1989, 59(2):121-128. PMID: 2719532

[33] Fisher ER, Kim WS. Primary clear cell thyroid carcinoma with squamous features. Cancer, 1977, 39(6):2497-2502. https://doi.org/10.1002/1097-0142(197706)39:6<2497::aid-c ncr2820390628>3.0.co;2-7 PMID: 872049 
[34] Carcangiu ML, Steeper T, Zampi G, Rosai J. Anaplastic thyroid carcinoma. A study of 70 cases. Am J Clin Pathol, 1985, 83(2):135-158. https://doi.org/10.1093/ajcp/83.2.135 PMID: 2578727

[35] Nonaka D, Tang Y, Chiriboga L, Rivera M, Ghossein R. Diagnostic utility of thyroid transcription factors Pax8 and TTF-2 (FoxE1) in thyroid epithelial neoplasms. Mod Pathol, 2008, 21(2):192-200. https://doi.org/10.1038/modpathol.380 1002 PMID: 18084247

[36] Bishop JA, Sharma R, Westra WH. PAX8 immunostaining of anaplastic thyroid carcinoma: a reliable means of discerning thyroid origin for undifferentiated tumors of the head and neck. Hum Pathol, 2011, 42(12):1873-1877. https://doi.org/ 10.1016/j.humpath.2011.02.004 PMID: 21663937

[37] Lee SM, Policarpio-Nicolas ML. Thyroid paraganglioma. Arch Pathol Lab Med, 2015, 139(8):1062-1067. https://doi.org/10. 5858/arpa.2013-0703-RS PMID: 26230601

[38] Cimino-Mathews A, Sharma R, Netto GJ. Diagnostic use of PAX8, CAIX, TTF-1, and TGB in metastatic renal cell carcinoma of the thyroid. Am J Surg Pathol, 2011, 35(5):757-761. https:// doi.org/10.1097/PAS.0b013e3182147fa8 PMID: 21451364 PMCID: PMC3449147

[39] Mowat A, Reid R, Mackie R. Balloon cell metastatic melanoma an important differential in the diagnosis of clear cell tumours. Histopathology, 1994, 24(5):469-472. https://doi.org/10.1111/ j.1365-2559.1994.tb00556.x PMID: 8088719
[40] Lee L, Zhou F, Simms A, Wieczorek R, Fang Y, SubietasMayol A, Wang B, Heller P, Huang H, Pei Z, Osman I, Meehan S, Lee P. Metastatic balloon cell malignant melanoma: a case report and literature review. Int J Clin Exp Pathol, 2011, 4(3): 315-321. PMID: 21487528 PMCID: PMC3071665

[41] Chavez-Alvarez S, Villarreal-Martinez A, Miranda-Maldonado I, Ocampo-Candiani J, Garza-Rodriguez V. Balloon cell melanoma and its metastasis, a rare entity. Am J Dermatopathol, 2017, 39(5):404-411. https://doi.org/10.1097/DAD.0000000000000 794 PMID: 27984232

[42] Willis BC, Johnson G, Wang J, Cohen C. SOX10: a useful marker for identifying metastatic melanoma in sentinel lymph nodes. Appl Immunohistochem Mol Morphol, 2015, 23(2):109112. https://doi.org/10.1097/PAl.0000000000000097 PMID: 25356946

[43] Xue $Y$, Wang Q, He X. Clear cell variant of diffuse large B-cell lymphoma: a case report and review of the literature. Int $\mathrm{J}$ Clin Exp Pathol, 2015, 8(6):7594-7599. PMID: 26261675 PMCID: PMC4526009

[44] Ronen S, Rothschild M, Ollague J, Suster S. Clear cell primary cutaneous anaplastic large cell lymphoma. Am J Dermatopathol, 2019, 41(10):e111-e115. https://doi.org/10.1097/DAD. 0000000000001422 PMID: 30946100

\section{Corresponding author}

José-Fernando Val-Bernal, Professor, MD, PhD, Pathology Unit, Department of Medical and Surgical Sciences, University of Cantabria, Avda. Cardenal Herrera Oria s/n, 39011 Santander, Spain; Phone +34 942 315098, Fax +34 942 315952, e-mail: fernando.val@unican.es

Received: March 20, 2020

Accepted: April 6, 2020 